\title{
Pengaruh Arsitektur Organik terhadap Bentuk Bangunan Sirkuit Motocross di Mojokerto
}

\author{
Bayu Pratama Putra ${ }^{1}$, Randy P. Salisnanda ${ }^{2}$, Wiwik Widyo Widjajanti ${ }^{3}$ \\ 1,2,3 Jurusan Arsitektur, Fakultas Teknik Sipil dan Perencanaan, Institur Teknologi Adhi Tama Surabaya \\ Email: ${ }^{1}$ bayuomanistas@gmail.com
}

\begin{abstract}
Mojokerto Regency has concave teritory at the middle and high teritory at south and north. With this condition at Mojokerto regency then raise a club which enthusiast with offroad especially for motorcycle.Like at Mojokerto FaktualNews.co said that 2017 exactly in Sunday July 16th an event held at Ketapanrame Village,Trawas Regency and attended approximately by 1500 crosser try the obstacle at that territory although not a competition.About motocross race especially the circuit that used to race, a themes of architecture style related with this aspect must do carefully.For make building which appropiate with function and condition from the territory, so the writer use organic architecture in the theme for create the shape of buliding that appropriate with surrounding territory.The method that choosed for this plan and project is describetive method and analyze which in implementation all of source are using from literature and from the field so the output is analyze about study in case and territory data that use for project.The concept of motocross building project take mocro concept from leaf metaphor and then accorded to organic architecture principe like building as nature.
\end{abstract}

Keywords: Organic Architecture, Facade, Motocross

\begin{abstract}
Abstrak. Kabupaten Mojokerto merupakan daerah yang memiliki topografi cekung ditengah-tengah dan tinggi di bagian selatan dan utara. Dengan kondisi daerah yang sedemikian rupa maka muncullah di Kabupaten Mojokerto ini penggemar offroad, khususnya roda dua. Seperti halnya yang dilansir oleh MOJOKERTO, FaktualNews.co pada tahun 2017 tepatnya pada hari minggu tanggal 16 Juli event yang dilaksanakan di Desa Ketapanrame Kecamatan Trawas diikuti oleh sedikitnya 1500 crosser menjajal medan yang ada didaerah tersebut walapun bukan sebuah kompetisi. Terkait dengan balap motocross terutama sirkuit yang ditempati, sebuah tema yang berhubungan dengan aspek tersebut haruslah diperhatikan. Untuk menciptakan bangunan yang sesuai dengan fungsi dan kondisi dari kawasan ini maka penulis mengusung tema arsitektur organik yang menjadikan bentuk bangunan yang sesuai dengan lingkungan sekitar. Metode yang dipilih untuk perencanaan dan perancangan ini adalah metode deskriptif dan analisa yang mana dalam pelaksanaannya segala bentuk studi yang telah dilakukan baik itu lapangan dan literatur memberikan output berupa analisa,antara lain yaitu analisa studi banding dan tapak yang digunakan untuk perancangan. Untuk konsep rancangan bangunan motocross ini mengambil konsep makro metafora dari bentuk daun yang selanjutnya dikaitkan dengan prinsip arsitektur organik antara lain building as nature.
\end{abstract}

Kata Kunci: Arsitektur Organik, Fasad, Motocross

\section{Pendahuluan}

Menurut David Pearson pada tahun 2001, Arsitektur organik merupakan Arsitektur Organik adalah sebuah filosofi arsitektur yang mengangkat keselarasan antara tempat tinggal manusia dan alam melalui desain yang mendekatkan dengan harmonis antara lokasi bangunan, perabot, dan lingkungan menjadi bagian dari suatu komposisi, dipersatukan dan saling berhubungan. Dengan kondisi lokasi site yang berada di daerah yang masih alami maka tema ini akan cocok digunakan dalam bentuk bangunan tersebut nantinya. Bangunana kan lebih menyatu dengan alam.Selain itu dengan pemberian arsitektur organik pada bentuk bangunan akan berpengaruh juga pada lingkungannya kawasan ini adalah sebuah 
kawasan yang notabene lebih memanfaatkan alam sekitar terutama pada arena sirkuit yang hampir sepenuhnya memanfaatkan unsur elemen tanah.

Sedangkan Motocross sendiri adalah kejuaraan cross country yang dilaksanakan di dalam sirkuit dengan menggunakan rintangan - rintangan. Perlombaan ini terbuka untuk kendaraan jenis Motocross dan Enduro sesuai dengan buku peraturan teknik FIM Appendix 01, FIM Motocross Technical Rules. Motocross sendiri memiliki kategori atau kelas tersendiri untuk setiap balapannya. Motocross membutuhkan sebuah wadah dalam melakukan kegiatan balapnya yang notabene menggunakan rintangan - rintangan tanah. Sehingga dalam penerapan arsitektur organik ini memiliki pengaruh positif terhadap motocross jika dikaitkan dari tempat yang digunakan dan latar belakang dari motocross itu sendiri. Ditambah lagi di kebanyakan event motocross belum memiliki suatu bangunan tetap untuk kegiatan balapnya. Bentuk bangunan akan senada dengan tempat kegiatan motocross juga lokasi yang digunakan sebagai tempat berdirinya sirkuit tersebut.

\section{Tinjauan Pustaka}

Menurut David Pearson dalam jurnal. Tomohon Health-Spa \& Wellness Center (2017), "Penerapan Arsitektur Organik", menyebutkan bahwa konsep dasar new organic architecture antara lain : (a) Building as nature; di mana bentuk bangunan Arsitektur Organik terinspirasi dari ketidaklurusan organisme biologis.(b) Continuous present; Arsitektur Organik tidak pernah berhenti dan selalu dalam keadaan dinamis namun tetap membawa unsur keaslian dalam sebuah desain; (c) Form follows flow, Bentuk bangunan dengan Arsitektur Organik mengikuti aliran energi dari alam dalam hal ini dapat berupa angin, cahaya dan panas matahari, arus air, energi bumi dan lainnya; (d) Of the people; Desain Arsitektur Organik dipengaruhi oleh aktifitas - aktifitas yang diwadahi pada bangunan, tujuan bangunan,kebutuhan pengguna, kenyamanan penggunanya dan keinginan-keinginan penggunanya; (e) Of the hill, yang memiliki arti bahwa bangunan merupakan bagian dari site, bukan sekedar bangunan yang ditempatkan di atas sebuah site; (f) Of the materials, Ada kecenderungan penggunaan material tertentu dalam Arsitektur Organik.Material yang dipilih antara lain material alami, material lokal dan material yang dapat memproduksi bentuk bebas; (g)Youthful and unexpected, Arsitektur Organik biasanya memiliki karakter yang inkonvensional,profokatif, terlihat muda, menarik dan mengandung keceriaan anak-anak; (h) Living music, Arsitektur organik mengandung unsur musik modern, di mana mengandung keselarasan irama, dari segi struktur dan proporsi bangunan yang tidak simetris.

Untuk kajian pustaka mengenai dapat dijelaskan bahwa Motocross adalah kejuaraan cross country yang dilaksanakan didalam sirkuit dengan menggunakan rintangan - rintangan.Perlombaan in terbuka untuk kendaraan jenis Motocross dan Enduro sesuai dengan Buku Peraturan Teknik FIM Appendix 01, FIM Motocross Technical Rules, tahun 2017.Motocross sendiri memliki jenis balap yang berbagai macam antara lain : (a) Grasstrack, berdasarkan sumber sportku.com tahun 2017 Grasstrack merupakan jenis olahraga balap motor di lintasan offroad. Motor balap yang digunakan adalah yang dijual bebas di pasaran; (b) Trial game, dikutip dari trialgame.id tahun 2016 bahwa pada Trial game Lomba ini tidak menitikberatkan pada kecepetan namun kemampuan sang pengendara untuk menaklukan beragam rintangan. Dibutuhkan kemampuan ekstra bagi pesertanya untuk menaklukan rintangan seperti memanjat bukit batu, melewati pohon-pohon tumbang atau rintangan buatan seperti menaiki tangga; (c) Berdasarkan Peraturan Arenacross/Supercross (Ikatan Motor Indonesia, 2017), Arenacross/Supercross adalah kejuaraan bermotor yang dilangsungkan diarena (stadion) baik tertutup ataupun terbuka dengan menggunakan kendaraan Motocross dan lintasannya dibuat hanya untuk sementara dengan menggunakan bahan - bahan dari tanah atau pasir; (d) Enduro, tidak banyak informasi mengenai enduro ini akan tetapi berdasarkan www.superadventure.co.id tahun 2018 Enduro dilakukan di arena terbuka dengan rintangan alam yang masih alamiah

\section{Metode Penelitian}

Dalam penelitian yang diadakan metode yang digunakan adalah metode kualitatif dengan penedekatan deskriptif dan analisa yang berkaitan dengan sirkuit motocross di Mojokerto.(1) Deskripsi, dalam hal deskripsi hal - hal yang dideskripsikan untuk adalah mengenai kondisi lingkungan yang digunakan sebagai tempat berdidrinya sirkuit motocross tersebut; (2)Analisa, akan menjabarkan 
kaitannya dengan kondisi existing yang digunakan sebagai penyelesaian dari kondisi existing yang telah dideskripsikan jika terdapat suatu masalah yang berkaitan dengan hal - hal tertentu

\section{Analisa Tapak}

Tapak yang digunakan sebagai sirkuit motocross ini merupakan tapak yang berada di Jl. Plampangan Ds. Kesiman, Kec.Trawas, Kab.Mojokerto.Tapak ini memiliki luas sebesar 7 ha atau sekitar $7000 \mathrm{~m}^{2}$. Tapak memiliki batas - batas yaitu sebelah selatan adalah taman ganjaran, sebelah barat adalah SDN Kesiman, sebelah timur adalah persawahan sedangkan sebelah utara merupakan area pemukiman. Dari sekian batas - batas ini kemudian dengan kondisi tapak yang juga berkontur memunculkan beberapa analisa yang juga nantinya akan berpengaruh terhadap bentuk bangunan dari sirkuit motocross tersebut. Berikut analisa terkai dengan tapak.
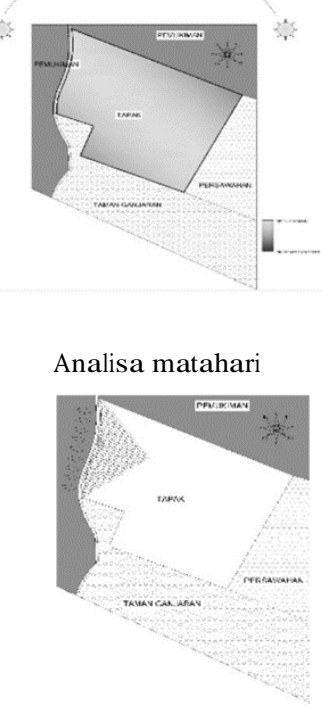

Analisa fokal poin
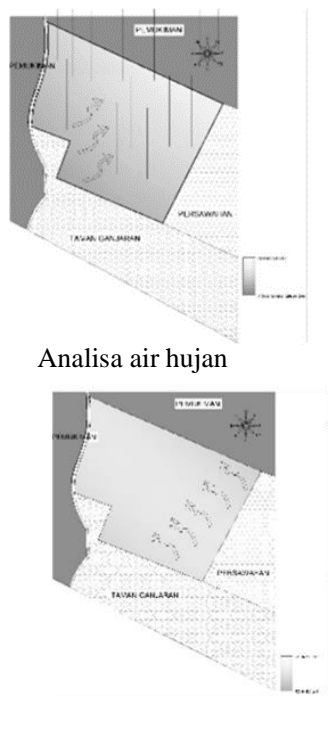

Analisa Angin

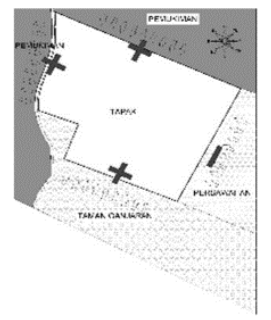

Analisa View to site

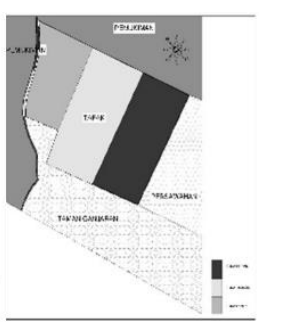

Analisa Aksesbilitas

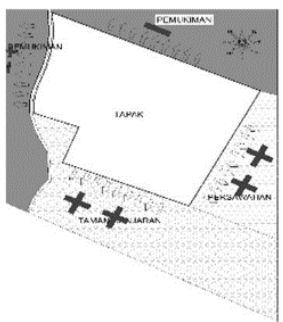

Analisa View From Site

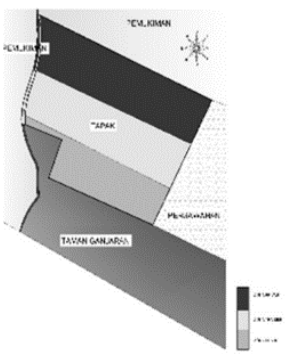

Analisa Kebisingan

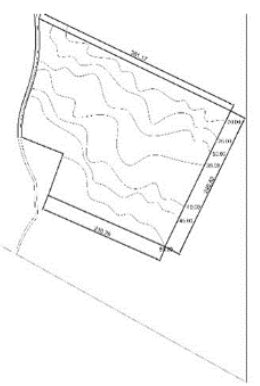

Analisa topografi

\section{Gambar 1. Analisis Tapak}

Dari sekian analisa tapak yang ada beberapa analisa yang sangat berpengaruh terhadap bentuk bangunan sirkuit motocross ini. Analisa - analisa tersebut seperti halnya analisa matahari yang berpengaruh pada finishing fasad, kemudian analisa angin yang berkaitan dengan cross ventilasi dan tentunya analisa fokal poin yang sangat berkaitan dengan orientasi bangunan yang akan didirikan. Dengan adanya analisa - analisa tersebut akan sangat membantu terhadap bentuk arsitektur organik. Berkaitan dengan konsep yang dipilih untuk bangunan sirkuit motocross sudah jelas bahwa penerapan arsitektur organik adalah yang terpenting,namun untuk ada konsep utama yang berkaitan dengan arsitektur organik haruslah diambil dari hal yang menjadi inti dari arsitektur organik itu sendiri. Sehingga dalam bentuk bangunan sirkuit motocross ini mengambil salah satu ciri dari arsitektur yang dikemukakan oleh David Pearson yaitu building as nature atau banggunan seperti alam. Dapat 
ditarik benang benang merah bahwa bangunan arsitektur organik ini memiliki bentuk seperti bentuk bentuk yang terjadi di alam. Bentuk yang tidak beraturan dan tidak bersudut. Bentuk tersebut bisa diambil dari apapun yang ada di alam. Hewan dan tumbuhan bisa jadi salah satu dasar metafora atau transformasi bentuk dari bangunan, bahkan aliran sungau juga bisa digunakan atau menjadi dasar bentuk dari arsitektur organik.

\section{Perancangan}

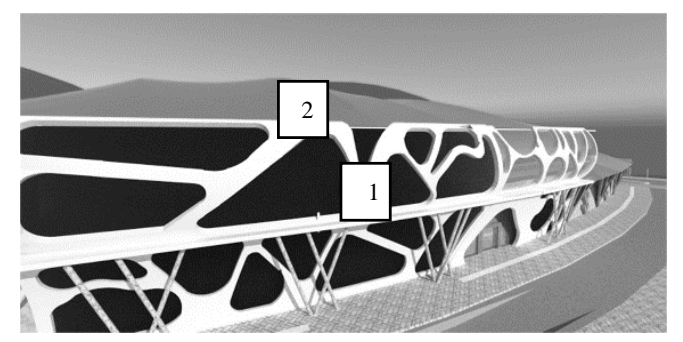

Gambar 2. Tampilan Bentuk Bangunan 1

Hasil rancangan yang diperoleh adalah bentuk bangunan yang berasal dari bentukan organisme makhluk hidup terkecil (1) yang mana gedung pada sirkuit motocross tersebut akan digunakan sebagai tempat pujasera dan minimarket bagi pengunjung yang berada di kawasan sirkuit motocross. Bentuk daun diterapkan pada atap yaitu sebagai penutup bagi dinding yang berdiri di bawahnya (2). Sedangkan untuk badan bangunan merupakan transformasi dari bentuk tulang daun yang telah dipotong sedemikian rupa membentuk bentukan layaknya sebuah organisme makhluk hidup terkecil seperti amoeba yang kemudian digunakan sebagai secondary skin untuk menghindari sinar matahari yang berlebihan.

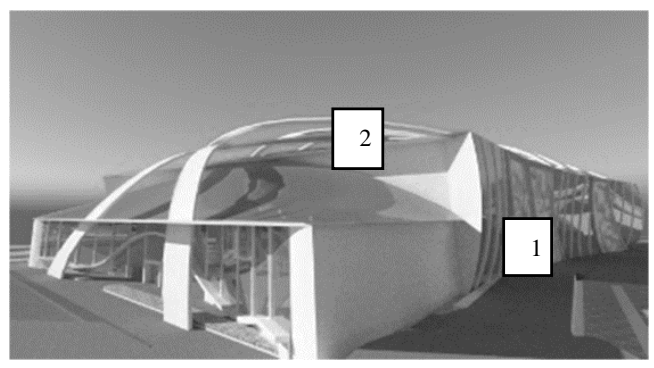

Gambar 3. Tampilan Bentuk Bangunan 2

Begitu juga dengan bentuk bangunan yang lain seperti halnya untuk tempat pelatihan motocross pada gambar di atas yang juga memanfaatkan bentuk alam yang diterapkan pada fasad dinding bangunan sisi kanan dan kiri (1). Bentukan akar dari sebuah pohon yang berakar jauh kedalam tanah di tempatkan sebagai sebuah ukiran dinding sedangkan bagian depan terdapat finishing permainan kolom pada lobby yang merupakan bentukan dari sebuah tulang daun, mengingat atap yang ada pada bangunan merupakan transformasi dari daun (2). Sehingga untuk memberi sebuah keterkaitan maka tulang daunlah yang kemudian di letakkan di atasnya sebagai pemanis tambahan. Lobby sendiri menggunakan kaca untuk fasad depannya disertai dengan permainan lekukan garis yang terinsipirasi dari sebuah bentukan alam yang tidak simetris, yang kemudian dipadukan dengan fasad kacanya. 

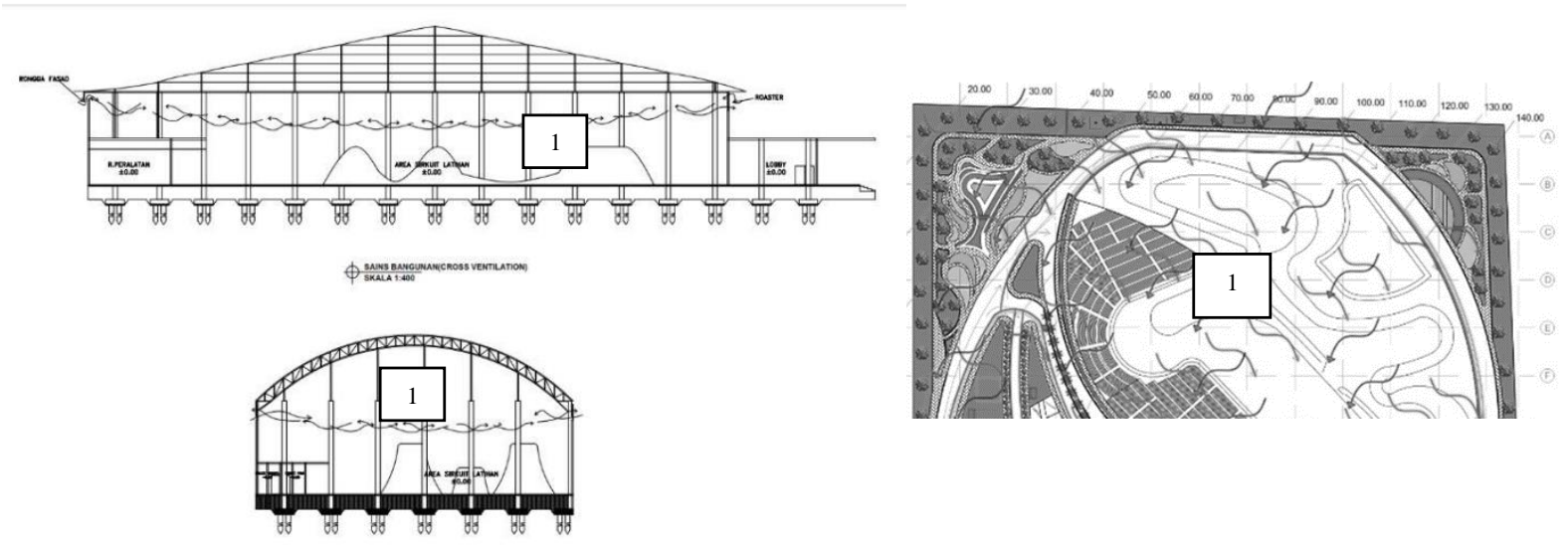

\section{Gambar 4. Aspek Sains Bangunan}

Sedangkan berkaitan dengan sains bangunan dari tiap massa dari yang tentunya menggunakan gaya atau style arsitektur organik juga harus diperhatikan. Sehingga dalam penerapannya untuk seperti halnya cross ventilation yang terdapat dalam setiap bangunannya menggunakan celah antara fasad dinding dengan atap sehingga pertukaran udara dapat bersirkulasi dengan baik (1). Meskipun pada fasad memiliki finishing menggunakan kaca yang tentunya tingkat peredaman panas yang tidak begitu efektif.

\section{Kesimpulan}

Pengaruh arsitektur organik pada bentuk bangunan sirkuit motocorss di Mojokerto adalah yang terbesar pada fasad bangunan. Fasad bangunan dengan ciri khas konsep building as nature yang menggunakan bentukan - bentukan dari alam untuk finishingnya. Dengan pemilihan konsep bangunan as nature atau arsitektur organik tersebut mampu merespon lingkungkungan sekitar sehingga mampu memberikan kenyamanan untuk semua penguna dari segi bangunan tanggap lingkungan. Selain itu pemilihan konsep tersebut juga bisa bersatu dengan lingkungan motocross yang memang berhubungan dengan alam bebas.

\section{Referensi}

IMI (Ikatan Motor Indonesia).2017. Peraturan Motocross.vol C:58 \& 122

Ixnando J. Ondang, Windy Mononimbar, Claudia S. Punuh.2017. Tomohon Health-Spa \& Wellness

Center.’Penerapan Arsitektur Organik". 6(2):84(arsitektur organik david pearson, 2001)

Suhartono. 2017. Nih Perbedaan Balap Motocross dan Grasstrack di https://sportku.com 
